\title{
EVALUATION OF PHOTOVOLTAIC SOLAR-POWERED WATER PUMPING IRRIGATION SYSTEM DURING WINTER SEASON
}

\author{
T. Z., Fouda *, A. A., Derbala ${ }^{* *}$,
}

A. H., Elmetwalli ${ }^{* * *}$ and Asmaa A. E. ${ }^{* * * * *}$

ABSTRACT

The experimental work was carried out at a private farm in Nubariah, Al Buhayrah Governorate, Egypt, which located at latitude and longitude angle of $30.07^{\circ} \mathrm{N}$ and $30.33^{\circ} \mathrm{E}$, respectively, during winter season (2016).The experiments were evaluated the performance of solar powered pump on a drip irrigation system. The photovoltaic water pumping system performance (sun tracking orientated facing south direction and tilt angle, horizontal and $30^{\circ}$, head pump, solar radiation) on the study indicator ( electric power output of panel W, panel efficiency \%, discharge of pump $m^{3} / h$, hydraulic power $W$,. The results showed that, the discharge of water pump increased from (33, 35, 36.5, 38.5 and 39.5 $\left.\mathrm{m}^{3} / \mathrm{h}\right)$ with solar radiation increased from $(622,711,740,752$ and 812 $\left.\mathrm{W} / \mathrm{m}^{2}\right)$ at constant of operating water head $30 \mathrm{~m}$ and tilt angle $\left(30^{\circ}\right)$, the discharge of water pump increased from $\left(32,34,36,37.5\right.$ and $\left.38 \mathrm{~m}^{3} / \mathrm{h}\right)$ with solar radiation increased from $\left(243,266,307,312\right.$ and $\left.527 \mathrm{~W} / \mathrm{m}^{2}\right)$ at constant of operating water head $30 \mathrm{~m}$ and horizontal plane in 17 January, 2016. When the operating water head change from (30, 35, 40, 45 to $50 \mathrm{~m}$ ) the discharge of water pump decreased from (33, 31.5, 29, 26 to $24.5 \mathrm{~m}^{3} / \mathrm{h}$ ) in 17 January, 2016. PV efficiency decreased from (18.7, $16.8,16.2,15.9$ and 16.5\%) with the temperature increased from $(19,20$, 21, 23 and $25^{\circ} \mathrm{c}$ ) with in 17 January, 2016. The hydraulic power increased from 2698 to $3229 \mathrm{~W}$ with the discharge increased from 33 to $39 \mathrm{~m}^{3} / \mathrm{h}$ in 17 January, 2016. This study recommended using pump powered by solar energy in drip irrigation system at the large area under the experimental conditions.

\footnotetext{
"Postgraduate of Agric. Eng. Dept., Fac. of Ag., Tanta. Univ., Egypt *** Associate Professor in Agric. Eng. Dept., Fac. of Ag., Tanta. Univ., Egypt **** Prof. of Agric .Eng .Dept ., Fac. of Ag., Tanta. Univ., Egypt
} 


\section{INTRODUCTION}

The photovoltaic water pumping systems (PVWPS) is considered as one of the most promising areas in photovoltaic applications.

1 Solar powered irrigation system can be a suitable alternative for farmers in the present state of energy crisis. Leung and Yang (2012) considered that, solar photovoltaic (PV) is one of the fastest growing renewable energy technology worldwide because of the rapid depletion and adverse environmental impact of fossil fuels. Svantesson and Linder (2012) defined, pv cells are solid state devices with no moving parts; therefore, nearly no maintenance is required for their simple and robust design. Khalil and Shaffe (2013) presented a comparative study of direct, diffuse and total solar radiation by using different models on horizontal and inclined surfaces in Cairo, Egypt. They found that three models provided a good estimation of the total solar radiation in the selected location. Foster and Cota (2014) showed that, photovoltaic water pumping (PVWP) has several beneficial characteristics including simplicity, reliability and cost effectiveness. The match between seasonal water needs and seasonal solar resource is a good one. "A typical system configuration includes a PV array, pump, controller, inverter for AC, and over current protection. Foster and Majid (2014) told that, the performance of PV water pump mainly depends on the water flow rate which is influenced by weather conditions at the location, especially solar irradiance and air temperature variations. The performance of solar pump depends on the water requirement, size of water storage tank, head (m) by which water has to be lifted, water to be pumped $\left(\mathrm{m}^{3}\right), \mathrm{PV}$ array virtual energy $(\mathrm{kWh})$, Energy at pump $(\mathrm{kWh})$, unused PV energy $(\mathrm{kWh})$, pump efficiency $(\%)$, and system efficiency (\%) and diurnal variation in pump pressure due to change in irradiance and pressure compensation. Chris (2016) defined, solar cell is a device which can catch the sun light and transform it to electrical energy directly. The size of a solar cell is about a size of a palm of an adult. The shape is an octagon, and the color is blue-black. Solar cells are built with the solar batteries together very often. The large units are solar modules. The case of many solar cells are built together which are called a solar panel. Narain and Winter (2016) found that, drip irrigation can reduce water consumption by $70 \%$ and 
fertilization consumption $40 \%$, whilst increasing crop yield by $50 \%$ when compared to flood irrigation, it has only been widely adopted in development countries. Paudyal and Shakya (2016) investigated the effects of dust on the efficiency of PV panels and presented a review of the degradation of a PV panel performance due to dust-induced physical damages, such as attenuation of the incident solar radiation and increases in the temperature of the PV module. Tiwari and Kalamkar (2016) have carried out the comparative performance analysis of four different PVWPS configurations under sunny day outdoor conditions at Nagpur, India and determined the best optimum configuration for the location and concluded that PV array optimization is one of the important factors to increase the overall efficiency and reduction in the cost of PVWP system. Rahman et al., (2017) investigated the effect of PV module temperature on the system energy efficiency. The researchers tested a photovoltaic (PV) system under Malaysian climatic conditions. It was shown that the electrical efficiency decreases by approximately $0.22 \%$ as the temperature of the PV module increases by $1{ }^{\circ} \mathrm{C}$. The researchers have also reported that solar cell temperature, solar irradiation intensity, mass flow rate of cooling fluids, humidity, and dust significantly affect the performance of PV modules. The objectives of theses study are to:

-Study the impact of the environmental conditions on solar powered pump discharge.

-Evaluated and tested the performance of solar powered pump on a drip irrigation system.

- Optimize the optimal parameter to maximize solar powered pump efficiency.

\section{MATERIALS AND METHODS}

The experimental work was carried out at a private farm in Nubariah, Al Buhayrah Governorate, Egypt, which located at latitude and longitude angle of $30.07^{\circ} \mathrm{N}$ and $30.33^{\circ} \mathrm{E}$, respectively, during winter season 2016 .

\section{Solar modules}

The system uses 40 modules (JKM250P-60). Each module measures length, $1650 \mathrm{~mm}$, width, $992 \mathrm{~mm}$, depth, $40 \mathrm{~mm}$, Weight, $19 \mathrm{~kg}$, and consists of 60 polycrystalline silicon cells connected in series and parallel. 


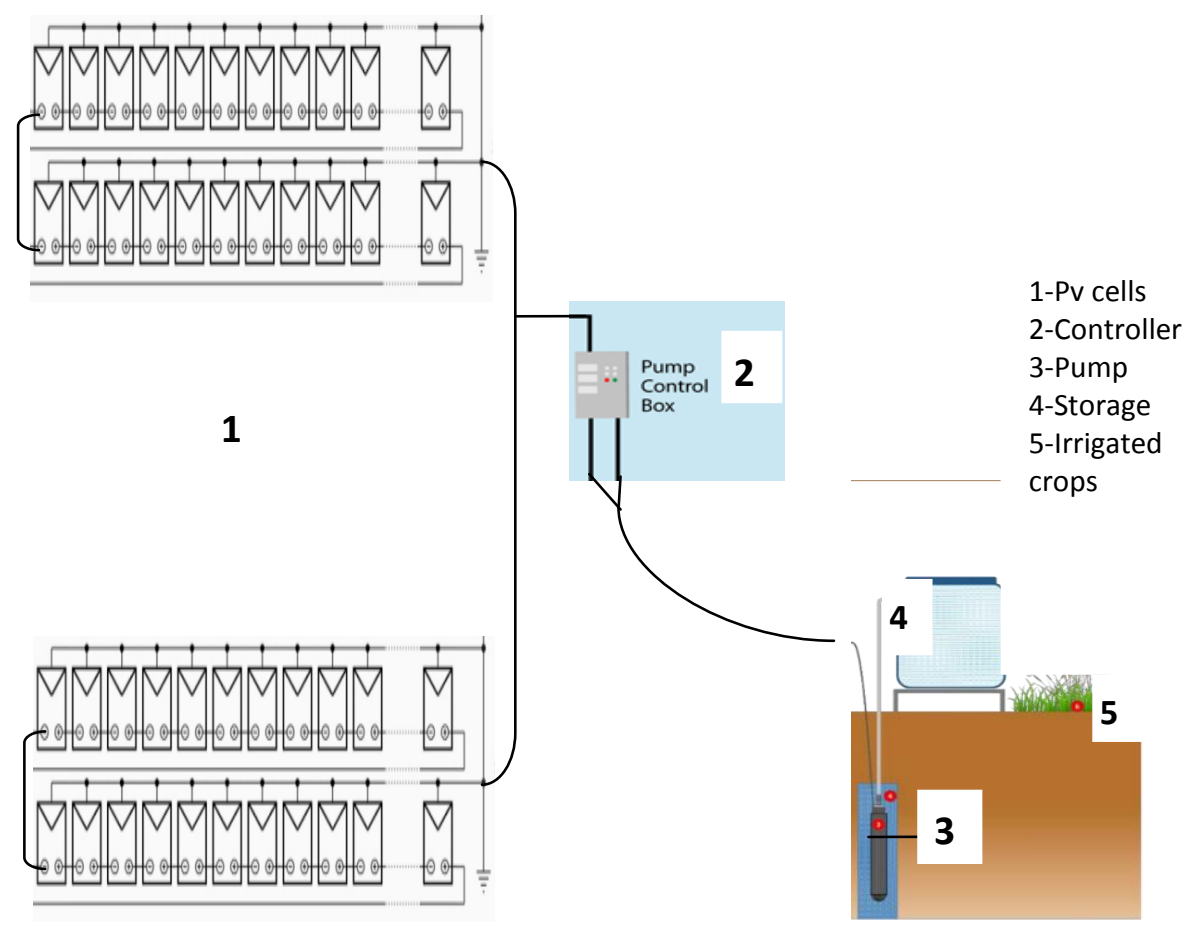

Fig.1: Solar pumping system

\section{Controller}

The system uses Controller PS9K2. Control input for dry running protection, remote control etc. Protected against overload and over temperature. Integrated MPPT (Maximum Power Point Tracking). The specification of controller PS9K2 is power, max. $10 \mathrm{Kw}$, input voltage, $\max .850 \mathrm{~V}$, optimum Vmp, >575 V, motor current, max. $17 \mathrm{~A}$, efficiency, max. 98\%, enclosure class, IP54, weight, $17 \mathrm{Kg}$.

\section{Pump Unit}

The system uses pump unit PU C-SJ30-7. Borehole diameter, min. 6.0 in, water temperature, $\max .30^{\circ} \mathrm{C}$, weight, $70 \mathrm{~kg}$.

\section{Instruments}

\section{Solar Power Meter}

TM-207 solar power meter measures solar radiation emitted from the sun in $\mathrm{W} / \mathrm{m}^{2}$ or BTU with a flexible sensor and is ideal for solar PV installations to set panels at optimal angles, for meteorological and agricultural applications. 


\section{The global positioning systems (GPS)}

The specification of GPS $72 \mathrm{H}$ is size, $3 \times 6.9 \times 15.75 \mathrm{~cm}$, weight, $224 \mathrm{~g}$, Gps accuracy, < 15 meters, RMS 95\% typical. To measure latitude and longitude angle.

\section{METHODS}

The experiments were done during winter season, 2016. The photovoltaic water pumping system performance (sun tracking orientated facing south direction and tilt angle, horizontal and $30^{\circ}$, head pump, solar radiation) on the study indicator (electric power output of panel W, panel efficiency \%, discharge of pump $\mathrm{m}^{3} / \mathrm{h}$, hydraulic power $\mathrm{W}$ ). The energy produced from solar cells powered the pump to provide the amount of water to the experimental area. The experimental area was $(650 \mathrm{~m} \times 220 \mathrm{~m})$. Forty modules of PV (connected in series, parallel) were used to provide the system with required electricity, each one is $(250 \mathrm{~W}$, polycrystalline, 37.7 $\mathrm{V}$ and $8.85 \mathrm{~A}$ ) with controller (17 A), pump unit is consist of (pump end, motor). In farm 5 crops are growed, distances agriculture $(\mathrm{m})$ in Grapes $(3 \times 2 \mathrm{~m})$, Pomegranate $(4 \times 6 \mathrm{~m})$, Mandarin $(4 \times 4 \mathrm{~m})$, Oranges $(4 \times 6 \mathrm{~m})$, Lemon $(4 \times 6 \mathrm{~m})$, number of plantes in feddan for Grapes, Pomegranate, Mandarin, Oranges, Lemon (700, 175, 262, 175, 175 tree), Production / feddan for one plant of Grapes, Pomegrante, Mandarin, Oranges, Lemon (12, 8, 10, 10, 15 ton/feddan), Production / tree for one plant of Grapes, Pomegrante, Mandarin, Oranges, Lemon (20, 30,50, 120,150 kilo/season). Irrigation system was consisted of GR drip lines. Its made with flowregulating cylindrical drippers that allow growers the ability to irrigate crops in a wide range of field conditions each one is diameter $(16,18,20$ and $32 \mathrm{~mm})$, thickness: $(0.7,0.9,1.0,1.1,1.2 \mathrm{~mm})$, roll length:(400 m), drippers spacing: $(20,25,30,40,50$ and $100 \mathrm{~cm})$. Flow rate: $(2,4,6$ and $8 \mathrm{l} / \mathrm{h}$ ). Pipes (PE) with a diameter of $63 \mathrm{~mm}$.

\section{The experimental factors}

1- Weather conditions

- Daily temperature in (winter)

- Daily solar radiation in (winter)

2- Panel performance

- Panel tilt angle $\left(0^{\circ}\right.$ and $30^{\circ}$ in winter $)$

- Panel orientation (east to west) 
3- Pump performance

-Pump head (30, 35, 40, 45, $50 \mathrm{~m})$

\section{Measurements and determinations}

PV panel efficiency

PV panel efficiency is the measure of how efficient the PV panel is in converting sunlight to electricity:

クpanel $=\left(\frac{\text { Voc } \times \text { Isc } \times \text { FF }}{\text { Ins } \times \mathbf{a}}\right) \times 100$

\section{Input and output power to the system}

The insolation to the PV gives the input power (Pin) to the system (Hamza and Taha, 1995):

$$
\text { Pin= Ins X A , W }
$$

The direct current output power (Pout) from the PV is given by

$$
\text { Pout= Voc X Isc . W }
$$

Where:

$$
\begin{array}{lll}
\text { Ins }=\text { Insolation, } \mathrm{W} / \mathrm{m}^{2} & , & \mathrm{~A}=\text { Solar module area, } \mathrm{m}^{2} \\
\text { Voc }=\text { Open circuit voltage, } \mathrm{V} & , & \mathrm{Isc}=\text { Short circuit current, A }
\end{array}
$$

\section{Hydraulic power}

The hydraulic power output of the pump is the power required to lift a volume of water through a given water head:

$\mathbf{P h}_{\mathbf{h}}=\boldsymbol{\rho} \times \mathbf{g} \times \mathbf{Q} \times \mathbf{H}, \mathbf{W}$

Where:

$$
\begin{array}{lll}
\rho=\text { Water density, } \mathrm{Kg} / \mathrm{m}^{3} & , & \mathrm{G}=\text { acceleration of gravity, } \mathrm{m} / \mathrm{s}^{2} \\
\mathrm{Q}=\text { Water discharge, } \mathrm{m}^{3} / \mathrm{s} & , & \mathrm{H}=\text { Total pumping water head, } \mathrm{m}
\end{array}
$$

\section{RESULTS AND DISCUSSION}

The effect of solar radiation and ambient temperature on photovoltaic

Fig.2. shows the relationship between solar radiation and ambient temperature versus time at different tilt angles $\left(0^{\circ}, 30^{\circ}\right)$ and fixed system in17 Jan, 2016. And from here also know the effect of tilt angle at fixed system (panel oriented to south along the day) in 17 Jan, 2016. The graph which is shown below the solar radiation on horizontal plane shows at any given time. the solar radiation on horizontal plane is approximately 
$243 \mathrm{~W} / \mathrm{m}^{2}$. The solar radiation on horizontal plane increases until it reaches the highest point of the path. The solar radiation on horizontal plane is approximately $527 \mathrm{~W} / \mathrm{m}^{2}$ at the highest point of the path. Then starts to decrease until it reaches the lowest point where is approximately $240 \mathrm{~W} / \mathrm{m}^{2}$. The solar radiation on tilted angle $30^{\circ}$ in fixed system is approximately $622 \mathrm{~W} / \mathrm{m}^{2}$. The solar radiation on tilted angle $30^{\circ}$ in fixed system increases until it reaches the highest point of the path. The solar radiation on tilted angle $30^{\circ}$ in fixed system is approximately $812 \mathrm{~W} / \mathrm{m}^{2}$ at the highest point of the path. Then starts to decrease until it reaches the lowest point where is approximately $292 \mathrm{~W} / \mathrm{m}^{2}$. The ambient temperature from 8:00 am to $12: 00 \mathrm{pm}$ starts to increase until it reaches the highest degree $\left(26^{\circ} \mathrm{c}\right)$ then starts to decrease until it reaches the degree $\left(21^{\circ} \mathrm{c}\right)$ at 16:00 pm. It is evident that solar radiation increases along day time from sunrise and reaches its maximum value then it decreases with sunset in winter. And from here found incident radiation on the panel increases with changing tilt angle gradually from $\left(0^{\circ}\right.$ to $\left.30^{\circ}\right)$.

Fig.3. it is evident that solar radiation increases from $(711,740,752,812$ $\mathrm{W} / \mathrm{m}^{2}$ ). The output electric power has the same trend of solar radiation where increases from $(285,338,412,432 \mathrm{~W})$. PV efficiency increases from $(15.9,16,16.5,17.9 \%)$.The output electric power and pv efficiency increases with the increasing in solar radiation.

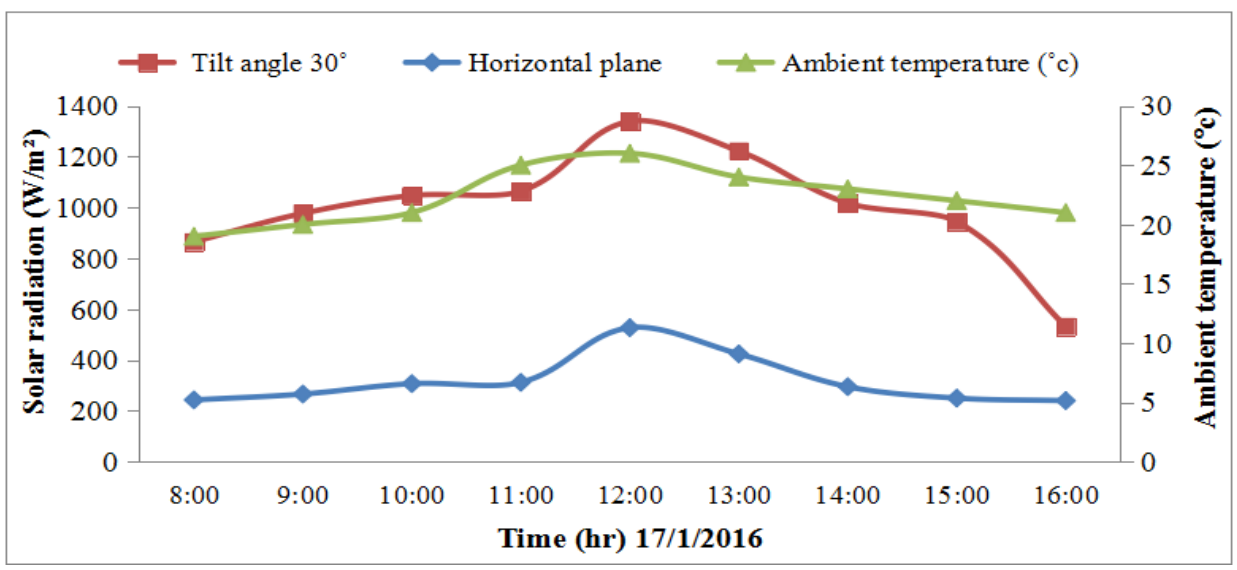

Fig. 2: Solar radiation and ambient temperature versus time at different tilt angles $\left(0^{\circ}, 3^{\circ}\right)$ and fixed system in $17 \mathrm{January}, 2016$. 


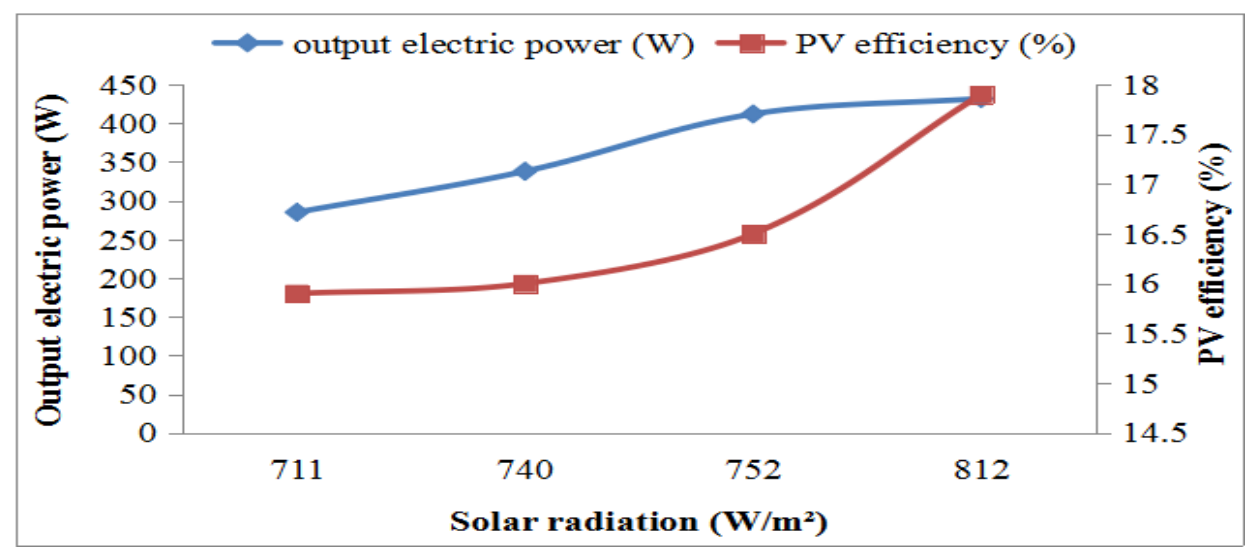

Fig. 3: Effect of different solar radiation on output electric power and pv efficiency in 17 January, 2016

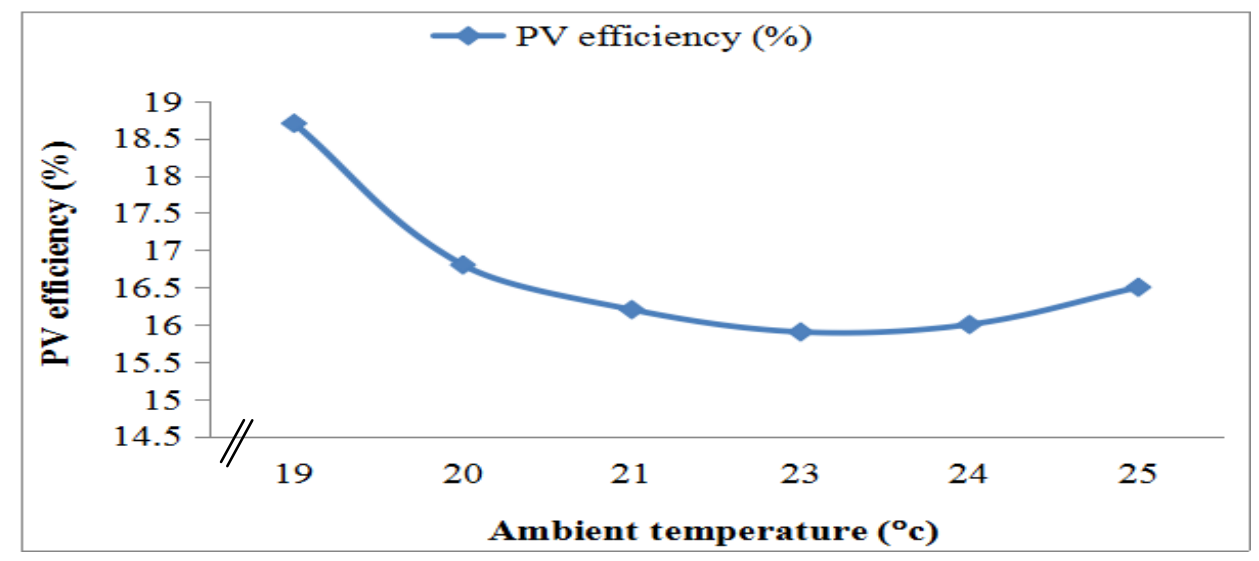

Fig. 4: Effect of different ambient temperature on pv efficiency in 17 January, 2016

Fig.4. shows that the relationship PV efficiency versus the ambient temperature in 17 January, 2016. at ambient temperature (19, 20, 21, 23 and $25^{\circ} \mathrm{c}$ ), PV efficiency was as follow (18.7, 16.8, 16.2, 15.9 and $16.5 \%$ ). It is evident that PV efficiency decreases with increasing temperature, fundamentally owing to increased internal carrier recombination rates, caused by increased carrier concentrations.

\section{Pump of discharge}

Fig.5. shows the relationship between pump discharge versus time in 17 January, 2016. The graph which is shown below. Pump discharge shows at any given time. Pump discharge increases until the mass reaches the 
highest point. Pump discharge is approximately $26 \mathrm{~m}^{3} / \mathrm{h}$ at the highest point. Then starts to decrease until it reaches the point where is approximately $20 \mathrm{~m}^{3} / \mathrm{h}$. It is evident that the discharge increases along day time from sunrise when it reaches its maximum value then it decreases with sunset.

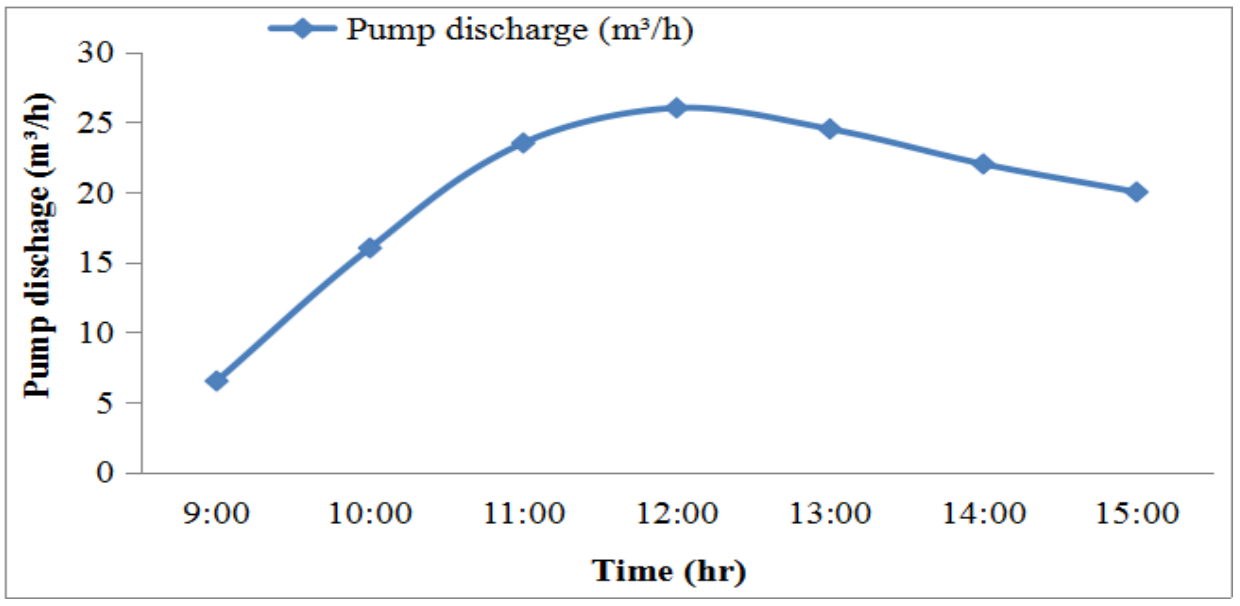

Fig. 5: The relationship between pump discharge versus time in 17

\section{January, 2016}

Fig.6. shows discharge versus solar radiation on tilted angle $30^{\circ}$ in fixed system and power at constant water head of $30 \mathrm{~m}$ in 17 January, 2016. Solar radiation increases from $\left(711,740,752,812 \mathrm{~W} / \mathrm{m}^{2}\right)$ pump discharge increases from $\left(35,36.5,38.5,39.5 \mathrm{~m}^{3} / \mathrm{h}\right)$, power increases from $(285$, $338,412,432 \mathrm{~W})$. It is evident that pump discharge and power increases with the increasing in solar radiation.

Fig.7. shows that the relationship pump discharge versus head in 17 January, 2016. Pump discharge decreases from (33, 31.5, 29, 26, 24.5 $\mathrm{m}^{3} / \mathrm{h}$ ) with the increase in water head from $(30,35,40,45,50 \mathrm{~m})$. It is evident that the discharge decreases with the increasing in water head.

\section{Hydraulic power}

Fig.8. shows the relationship solar radiation on tilted angle $30^{\circ}$ in fixed system versus hydraulic power in 17 January, 2016. Solar radiation increases from $\left(622,711,740,752,812 \mathrm{~W} / \mathrm{m}^{2}\right)$ hydraulic power increases from $(2698,2861.3,2984,3147.4,3229 \mathrm{~W})$. It is evident that hydraulic power increases with the increasing in solar radiation. 


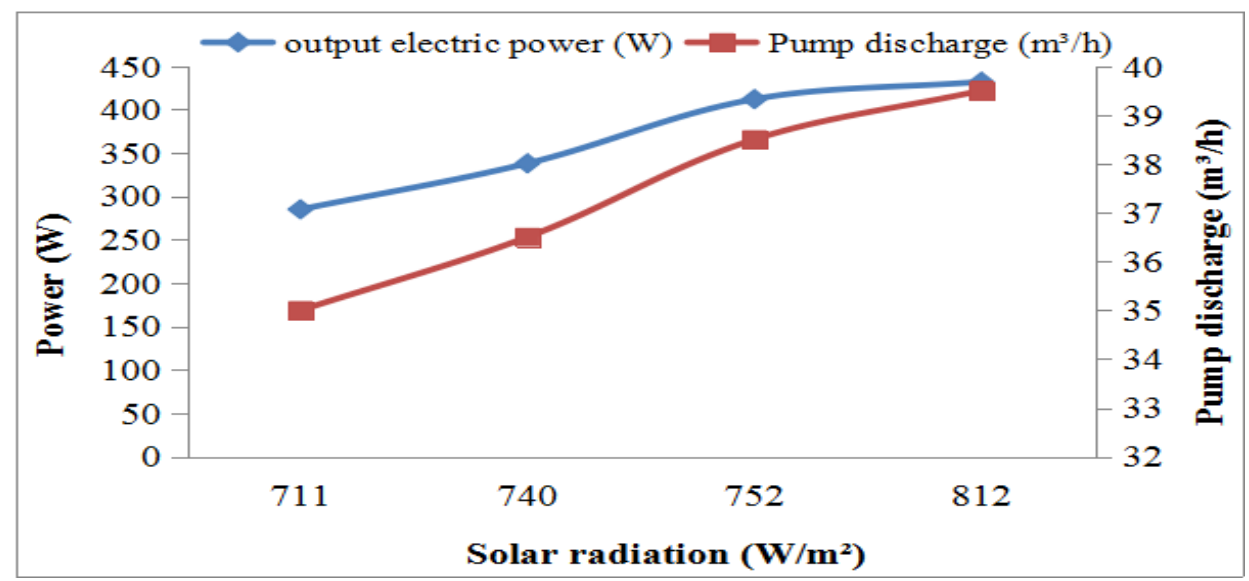

Fig.6: discharge versus solar radiation on tilted angle $30^{\circ}$ in fixed system and power at constant water head of $30 \mathrm{~m}$ in 17 January, 2016

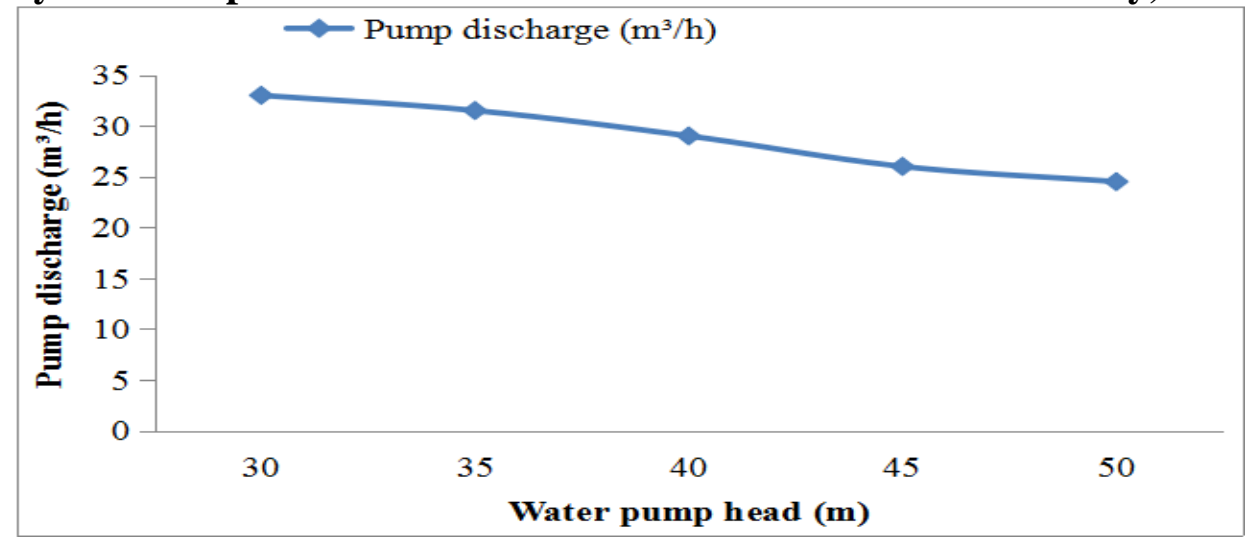

Fig.7: pump discharge versus head at different heads in 17 January, 2016

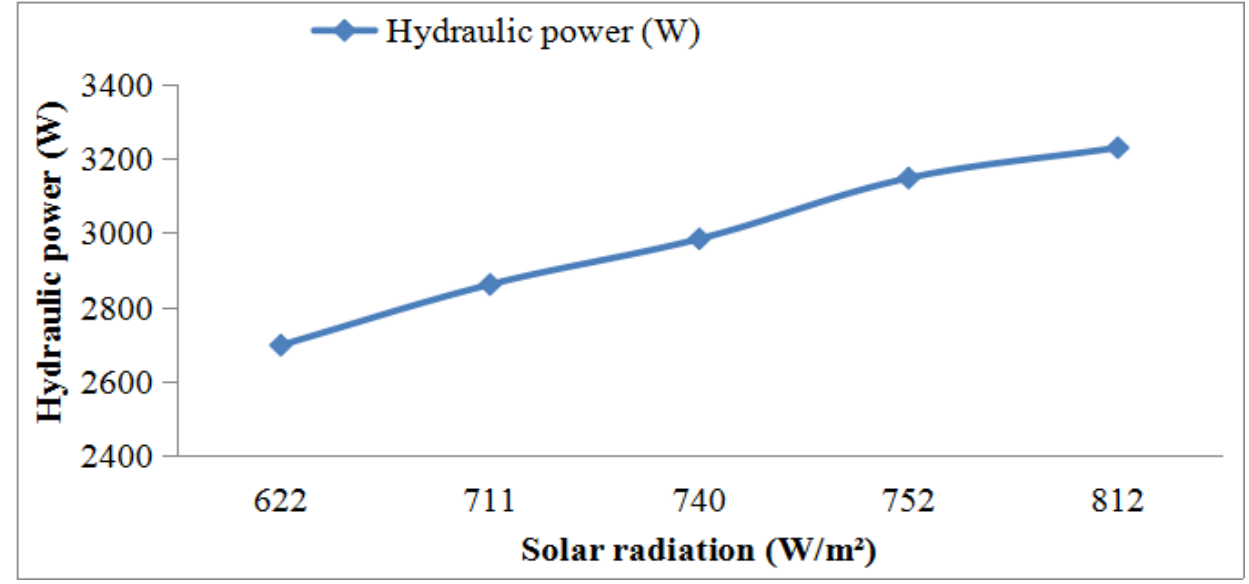

Fig. 8: The relationship solar radiation on tilted angle $30^{\circ}$ in fixed system versus hydraulic power in 17 January, 2016 
Fig.9. shows that the relationship pump discharge versus hydraulic power in 17 January, 2016. Hydraulic power increases from (2698, 2861.3, 2984, 3147.4, $3229 \mathrm{~W})$ pump discharge increases from $(33,35,36.5$, $38.5,39.5 \mathrm{~m}^{3} / \mathrm{h}$ ). It is evident that hydraulic power increases with the increasing in pump discharge.

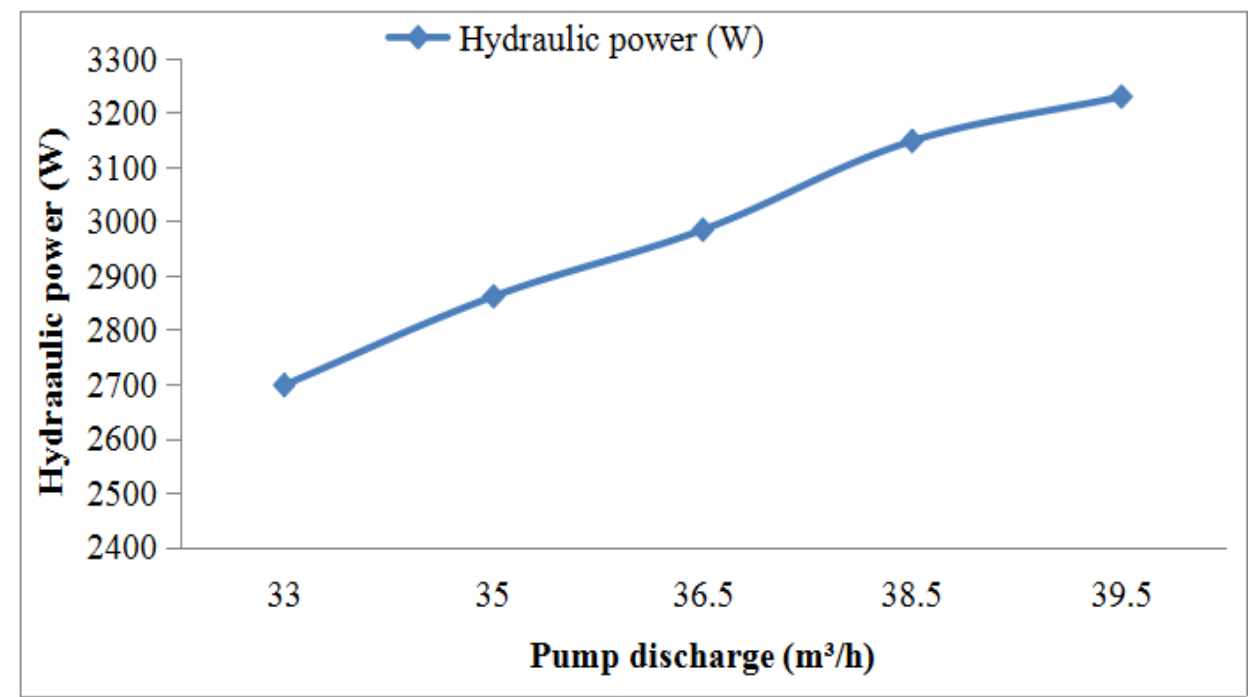

Fig. 9: The relationship pump discharge versus hydraulic power in 17 January, 2016

\section{CONCLUSION}

The photovoltaic water pumping systems is able to save the energy to remote locations where the electricity produced by the photovoltaic water pumping system better than the electricity produced by a diesel. When using the system found that output power from the system is $(285,338$, $412,432 \mathrm{~W})$ and input power to the system is (955.3, 1339.4, 1485,1548.2, $1570 \mathrm{~W}$ ) in 17 January, 2016.

\section{REFERENCES}

Chris(2016) Woodford on Solar cells. Available from:http://www. explainthatstuff.com/solarcells.html.

Foster R, Cota A, (2014) A test book of solar energy. Renew Energy; www.amazon.com/Solar-Energy-Renewable-Environmen). 
Foster R, Majid G, (2014) A test book of solar energy. Renew Energy; www.amazon.com/Solar-Energy-Renewable-Environmen).

Hamza and A. Z. Taha, (1995) Performance of submersible PV solar pumping systems under conditions in the Sudan. Renewable energy, vol. 6: pp. 491-495.

Khalil SA, Shaffie AM. (2013) A comparative study of total, direct and diffuse solar irradiance by using different models on horizontal and inclined surfaces for Cairo, Egypt. Renew Sustain Energy Rev.; 27: pp. 853-63.

Leung, D.Y.C., Yang, Y., (2012) Wind energy development and its environmental impact. Renew. Sustain. Energy; 16: pp. 1031-1039. Narain, J., and Winter, A., (2016) Mathematical Models of Complian tMembranes for Inline Drip Emitters. International Design Engineering Technical; pp. 1-5.

Paudyal B, Shakya S. (2016) Dust accumulation effect on efficiency of solar pv modules for off grid purpose: a case study of Kathmandu". Solar Energy: pp. 103-10.

Rahman, M. M., Hasanuzzaman, Md., Rahim, N. A., (2017) Effect of operational conditions on the energy efficiency of photovoltaic modules operating in Malaysia. Journal of Cleaner Production; 143: pp. 912-924.

Svantesson,J. and Linder, E. (2012) Solar electricity for rural house holds at the Fiji islands: a thesis presented in fulfilment of the requirements for the degree of Bachelor of Science in KTH School of Industrial Engineering and Management, Stockholm, Sweden.

Tiwari Arunendra K, Kalamkar Vilas R. (2016) Performance investiations of solar water pumping system using helical pump under th e outdoor condition of Nagpur, India. Renew Energy; 97: pp. $737-45$. 


\section{الملخص العربي}

\section{تقييم نظام ضخ مياه الرى بالخلايا الثمسية خلال موسم الشتاء}

طارق فوده*، أسعد درباله *، عادل المتولى* و أسماء البلكيمى هاء

نظر الزيادة تكاليف الكهرباء وعدم توفرها فى الاماكن البعيدة وكذلك صعوبة الحصول على على الكي

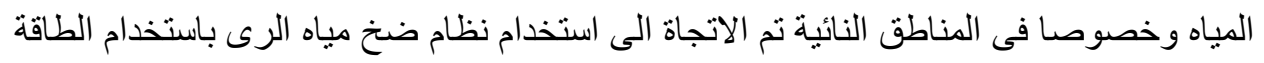
الثمسية لرى المحاصيل البستانية (العنب والرمان و البرتقال و اليوسفى و الليمون) باستخدام نظام

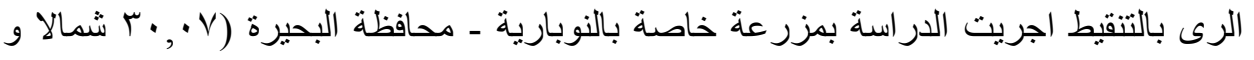

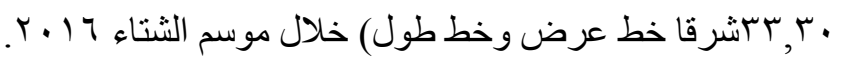
وكاتت أهداف الدراسة كما يلي:

1 ـ اختباروتقييم اداء مضخة تعمل بالطاقة الثمسية على اساس نظام الرى بالتنقيط.

r ـ در اسة تاثير الظروف البيئية على نظام ضخ مياه الرى بالطاقة الثمسية. ب - تحديد المعاملة الامثل لتحقيق اقصى قدر من الكفاءة فى نظام ضخ مياه الرى بالطاقة الثمسبة.

$$
\text { أخذت المؤشر ات التاليه فى الاعتبار }
$$

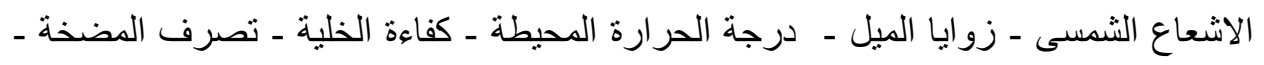
الضاغط ـ القدرة الهيدروليكية قد تم التوصل الى النتائج التاليه من خلائل التجارب الحقليه: ا ـ الاشعاع الشمسى زاد مع شروق الشمس الى ان وصل الى اقصى قيمة لله فى فترة الظهيرة ثم يقل مع غروب الثمس. حيث انه فى الوضع الافقى يبدا يزداد حتى يصل الى اعلى نقطة

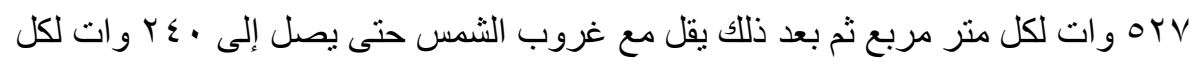

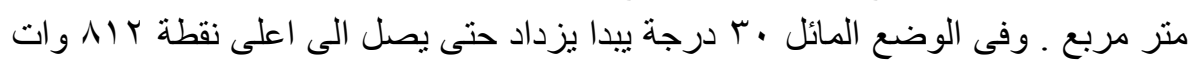
لكل متر مربع ثم بعد ذلك يقل مع غروب الثمس حتى يصل الى بـ بو بو ات لكل منر مربع.

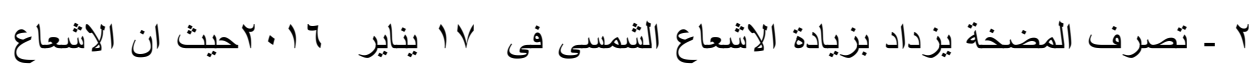

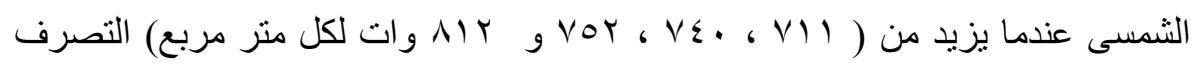

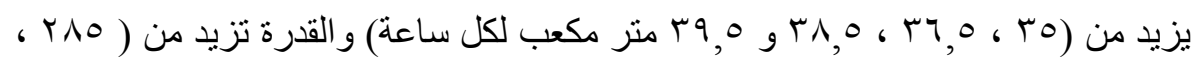

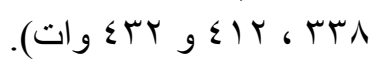

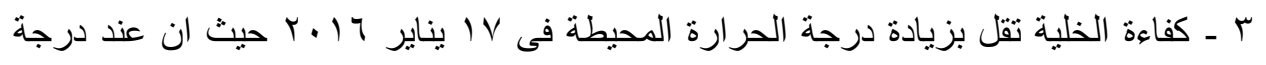

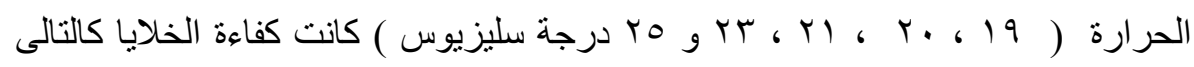

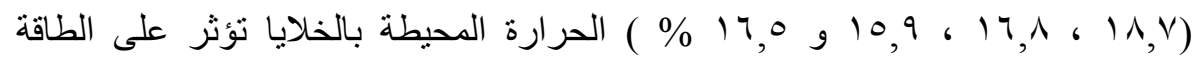
الكهربائية الناتجة من الخلايا وبالتالى اداء وكفاءة الخلايا تقل.

*قسم الهندسة الزراعية ـ كلية الزراعة - جامعة طنطا. 


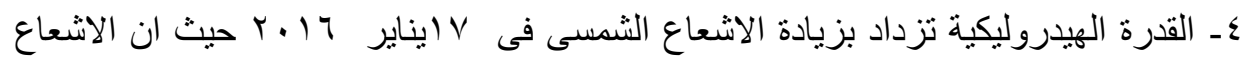

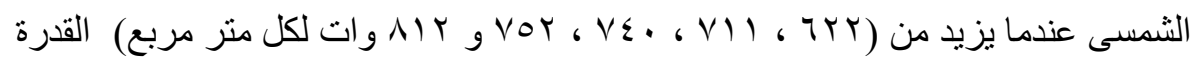
الهيدروليكية تزيد من ( (

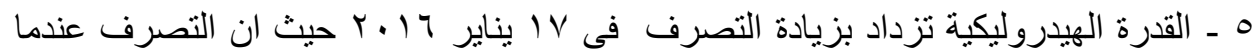

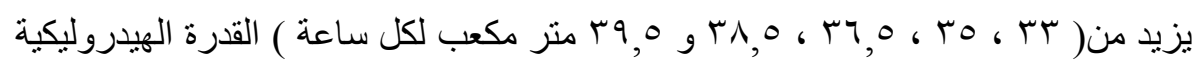
تزيد من ( ) تزيد من (

7 - زاد تصرف المضخة مع شروق الثمس الى ان وصل الى اقصى قيمة له فى فترة الظهيرة

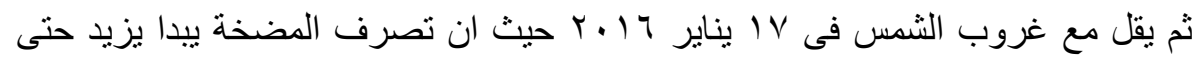

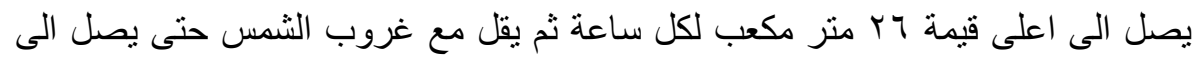
. أمتر مكعب لكل ساعة.

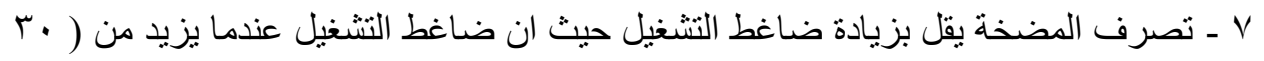

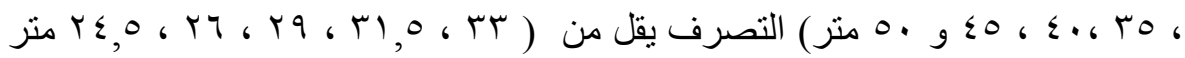
مكعب لكل ساعة). 